\title{
Acute Toxicological Assessment and Investigation of Cardioprotective Potential of Processed Pumpkin (Cucurbita Maxima) Seed Flour
}

\author{
Beatrice Olawumi Temilade Ifesan ${ }^{1 *}$, Adeyanmola Oluwaseyi Akintade ${ }^{2}$, Olamide Olajusi Crown ${ }^{3}$, Mary $^{2}$ \\ Tolulope Olaleye ${ }^{3}$, Olugbenga Olufemi Awolu ${ }^{1}$ and Olaiya Peter Aiyelari ${ }^{4}$
}

${ }^{1}$ Department of Food Science and Technology, Federal University of Technology, Nigeria

${ }^{2}$ Department of Food Science and Technology, Olusegun Agagu University of Science and Technology, Nigeria

${ }^{3}$ Department of Biochemistry, Federal University of Technology, Nigeria

${ }^{4}$ Department of Crop Soil and Pest Management, Federal University of Technology, Nigeria

*Corresponding author: Beatrice Olawumi Temilade Ifesan, Department of Food Science and Technology, Federal University of Technology, Akure, Nigeria.
Received Date: November 01, 2021

Published Date: November 22, 2021

\begin{abstract}
Pumpkin seeds (Cucurbita maxima) are medicinally useful. It has pharmacological activities such as anti-diabetic, anti-fungal, anti-bacterial, anti-inflammation activities, antioxidant effects. The in vitro antioxidant capacity of the processed pumpkin seed flour was investigated. In addition, the acute toxicological assay was carried out by grouping experimental male rats $(150-200 \mathrm{~g})$ into four groups (n=5). Each of the groups were fed with each of the processed samples $(100 \%)$ respectively, except control that was fed normal rat chow for two weeks. The cardioprotective property of the processed sample was further investigated. The experimental animals were divided into nine groups $(\mathrm{n}=5)$ each and at the end of two weeks, the heart, liver, and blood were obtained for biochemical parameters. Fermented C. maxima seed flour exhibited the highest antioxidant properties. The acute toxicological result revealed that processed seeds flour caused significant alteration in the activities/levels of serum biochemical indices and the antioxidant parameters in the heart and liver as compared with the control. In addition, the cardioprotective study revealed that doxorubicin intoxication caused significant alterations in the cardiac serum biochemical indices, lipid profile, electrolytes, and cardiac antioxidant parameters Also, doxorubicin caused a dose-dependent elevation in the atherogenic indices. However, pretreatment with processed C. maxima seed flour significantly prevented most of these derangement in a comparable manner to that of induced group. This study revealed that processed C. maxima seed flour especially fermented sample at $60 \%$ diet supplement offered protection against doxorubicin-induced cardiotoxicity probably via antioxidative and antihyperlipidemic mechanisms.
\end{abstract}

Keywords: Cucurbita maxima; Cardiotoxicity; Doxorubicin; Antioxidants; Antihyperlipidemic

\section{Introduction}

Cardiovascular diseases (CVD) are major cause of disability and premature death throughout the world and accounts for a large proportion of global deaths from all causes. An estimated 17.9 million people died from cardiovascular diseases in 2016, representing $31 \%$ of all global deaths. Of these deaths, $85 \%$ were due to heart attacks and stroke [1]. According to the World Health Organization, cardiovascular diseases include coronary heart disease (heart attacks), cerebrovascular disease, raised blood pressure (hyperten sion), peripheral artery disease, rheumatic heart disease, congenital heart disease and heart failure [1]. Generation of free radicals in the body beyond its antioxidant capacity leads to oxidative stress which has been implicated in the etiology or exacerbation of many diseases including cardiovascular disease [2]. Management of cardiovascular- related disorders among poor populace in Nigeria has remained unaffordable, due to high cost of cardioprotective drugs and inaccessible health care [3]. In general, cardioprotective drugs 
have toxic side effect [4]. Doxorubicin is an anthracycline antibiotic used in treatment of cancers (acute leukemia, sarcomas, and malignant lymphoma, breast cancer and ovarian cancer) [5]. However, this drug has been used overtime as cardiotoxicity agent [6], due to its dose-dependent chronic cardiotoxicity that is characterized by an irreversible dilated cardiomyopathy and congestive heart failure [7].

The cardioprotective ability of various medicinal plants and their products have been reported [8]. Pumpkin (Cucurbita maxi$m a$ ) is gaining popularity among modern physicians and its seeds and oil are already packaged as over the counter supplements (pumpkin seed softgel capsules, pumpkin seed protein supplement and pumpkin seed oil press) in developed countries in the management of various diseases such as (benign prostate hyperplasia, vision problems, heart failure and high blood pressure) $[9,10]$. Due to poor management of cardiovascular related disorders among the poor, there is need to source for a cheaper, accessible, and edible drug or supplement. Hence, this study seeks to evaluate the effects of processed pumpkin seed on some biomarkers using albino rats.

\section{Material and Method}

Doxorubicin (DOX) and Ramipril, a product of Sigma pharmaceuticals, China, and Lupin Pharmaceuticals, India, aspartate transaminase (AST), alanine transaminase (ALT), lactate dehydrogenase (LDH), creatine kinase (CK) and lipid profile assay kits were obtained from Randox laboratories, UK. Albumin and electrolyte kits (potassium and sodium) were obtained from Teco Diagnostics, USA. All other chemicals used were of the highest grade commercially available.

\section{Plant material}

The pumpkin (Cucurbita maxima) used for this study was planted at Federal University of Technology, Akure farm, Nigeria around May 2017. Mature fruits were harvested and brought to the laboratory for further processing.

\section{Ethics statement}

Ethical Committee of School of Agriculture and Agricultural Technology, Federal University of Technology, Akure, Nigeria (FUTA/SAAT/2019/011) approved the study protocol. The experiment on the animals were conducted in accordance with the Code of Ethics of the World Medical Association.

\section{Experimental animals}

Healthy adult albino rats (Wistar strain) weighing between 150 - $200 \mathrm{~g}$ were purchased from the Central Animal House of University of Ibadan, Nigeria

\section{Preparation of processed pumpkin seed flour}

Fermented Cucurbita maxima seed flour: Fermented pumpkin seed flour was prepared using the method described by [11] with slight modification. The seeds were sorted and boiled for 20 mins, drained, wrapped with blanched banana leaves, allowed to ferment for five days at room temperature, dried, milled and sieved to obtained fine flour.

Germinated Cucurbita maxima seed flour: Germination was carried out by the method described by [12]. The pumpkin seeds after been sorted from its fruit was soaked in water for $12 \mathrm{~h}$ overnight. The water was drained off, the steeped pumpkin seed were spread on moistened jute bag and covered to germinate at room temperature for 3 days with regular wetting and turning of seeds. After sprouting, the seeds were dried in an oven (Model No. DHG9101.ISA) at $60 \mathrm{oC}$ for $4 \mathrm{~h}$. The sprouts were removed from the dried seeds, milled into flour, sieved, kept in airtight container and labeled.

Roasted Cucurbita maxima seed flour: The production of roasted pumpkin seed flour was done according to the method described by [13] with slight modification. Pumpkin seeds were manually removed from the fruit, washed, boiled with salt for $10 \mathrm{mins}$, air dried and roasted in an earthen pot with coarse sand (which was properly washed and sun-dried before use). The roasted pumpkin seed was allowed to cool, milled into flour, sieved, and then stored in a tight jar container for various analyses.

\section{Antioxidant properties of processed Cucurbita maxima seed flour}

Determination of total phenol content: Total phenol content (TPC) was determined by Folin-Ciocalteu assay according to [14] using gallic acid as a standard. Fifty microliters of the aqueous extract solution containing $0.5 \mathrm{mg}$ of aqueous extract was dispensed into a test tube, $50 \mu \mathrm{l}$ of distilled water and $500 \mu \mathrm{l}$ of Folin-Ciocalteu reagent was added respectively and shaken thoroughly. After 3 min, $400 \mu \mathrm{l}$ of $7.5 \%$ sodium carbonate solution was added and the mixture was incubated at $450 \mathrm{C}$ in a water bath for $40 \mathrm{~min}$. Absorbance was measured at $765 \mathrm{~nm}$ against blank. The same procedure was repeated to all standard tannic acid solution $(0.1 \mathrm{mg} / \mathrm{ml})$. The blank is a mixture of $100 \mu \mathrm{l}$ of distilled water, $500 \mu \mathrm{l}$ of Folin-Ciocalteu reagent and $400 \mu \mathrm{l}$ of $7.5 \%$ sodium carbonate.

Determination of total flavonoid content: Total flavonoid content was determined by aluminum chloride colorimetric assay with slight modification according to [15] About $500 \mu \mathrm{l}$ of methanol was added to $10 \mathrm{ml}$ flask containing $500 \mu \mathrm{l}$ of aqueous extract. To this $50 \mu \mathrm{l}, 10 \% \mathrm{AlCl} 3$ and $50 \mu \mathrm{l}$ of $1 \mathrm{M} \mathrm{CH} 3 \mathrm{COOH}$ was added respectively. The total volume was made up to $2500 \mu \mathrm{l}$ with distilled water. The solution was then incubated at room temperature for $30 \mathrm{~min}$. Absorbance was read against blank at $415 \mathrm{~nm}$ with spectrophotometer.

Determination of vitamin C concentration: Ascorbic acid was analyzed by the modified spectrophotometric method as described by [16]. Seventy-five microlitres of dinitrophenylhydrazine was dispensed into a test tube, $300 \mu \mathrm{l}$ of sample aqueous extract, $100 \mu \mathrm{l}$ of distilled water and $100 \mu \mathrm{l} 13 \%$ trichloroacetic acid was added into the test tube respectively and the mixture was incubated at $370 \mathrm{C}$ for $3 \mathrm{~h}$. After $3 \mathrm{~h}, 500 \mu \mathrm{l}$ of $65 \% \mathrm{H} 2 \mathrm{SO} 4$ was added, and the absorbance of the mixture was read against blank at $520 \mathrm{~nm}$. 
The same procedure was repeated for the standard, but sample extract was replaced with vitamin C. The blank is a mixture of $75 \mu \mathrm{l}$ of DNPH, $400 \mu \mathrm{l}$ of distilled water, $100 \mu \mathrm{l} 13 \%$ TCA and $500 \mu \mathrm{l}$ of $65 \%$ H2SO4. The ascorbic acid content was expressed as ascorbic acid equivalent (AAE) per gram of sample (mg of AAE/g sample).

Determination of ferric reducing antioxidant power (FRAP): The reducing property of the extract was determined by [17] method. About $0.25 \mathrm{ml}$ of the extract was mixed with $0.25 \mathrm{ml}$ of $200 \mathrm{~m} \mathrm{M}$ of Sodium phosphate buffer pH 6.6 and $0.25 \mathrm{ml}$ of $1 \%$ Potassium Ferroyanide (KFC). The mixture was incubated at $500 \mathrm{C}$ for $20 \mathrm{~min}$, there after $0.25 \mathrm{ml}$ of $10 \%$ Trichloroacetic acid (TCA) was also added and centrifuged at $2000 \mathrm{rpm}$ for $10 \mathrm{~min}$. One $\mathrm{ml}$ of the supernatant was mixed with $1 \mathrm{ml}$ of distilled water and $0.1 \%$ of $\mathrm{FeCl} 3$ and the absorbance was measured at $700 \mathrm{~nm}$.

Determination of 2, 2-Diphenyl-picryl-hydrazyl (DPPH) radical scavenging ability: The ability of the pumpkin seed extract to scavenge DPPH free radical was carried out according to the method described by [18]. Twenty microlitre, $40 \mu \mathrm{l}, 60 \mu \mathrm{l}$ and $80 \mu \mathrm{l}$ of the aqueous extract (containing $2 \mathrm{mg}$, $4 \mathrm{mg}, 6 \mathrm{mg}$ and $8 \mathrm{mg}$ of the sample respectively) was dispensed into test tubes and made up to $580 \mu \mathrm{l}$ with distilled water followed by addition of $600 \mu \mathrm{l}$ of DPPH in methanol and incubated in the dark at room temperature for $15 \mathrm{~min}$. After incubation period, the absorbance was read against blank at $517 \mathrm{~nm}$.

Determination of 2,2-azinobis(3-ethylbenzo-thiazoline-6-sulfonate) (ABTS*) scavenging ability: The (ABTS) scavenging ability of the extract sample was assayed on the basis of a protocol as represented by [19]. Hundred microlitre of the extract solution containing $2.0 \mathrm{mg}$ sample was dispensed into test tubes, made up to $200 \mu \mathrm{l}$ with distilled water after which $1800 \mu \mathrm{l}$ of ABTS solution was added and the mixture was incubated at room temperature in the dark for $15 \mathrm{~min}$. The extract ability to scavenge the radical was determined spectrophotometrically by an absorbance measurement against distilled water as blank, at a wavelength of $734 \mathrm{~nm}$.

\section{Animal handling and treatment}

The animals were housed in the primate colony of the Department of Biochemistry, Federal University of Technology, Akure, Nigeria. The animals were kept in wire mesh cages under controlled light cycle (12h light/12h dark), fed with commercial rat chow (Vital Feeds Nigeria Limited) ad libitum, and liberally supplied with water.

\section{Acute toxicological assay}

Experimental rats were divided into four groups (I-IV) of five animals each. Group 1 served as control while groups 2-4 were fed $100 \%$ of germinated, fermented, and roasted C. maxma seed flour, respectively for two weeks. Animals were sacrificed $24 \mathrm{~h}$ after the last feeding, the blood was collected through cardiac puncture into a plain bottle. The blood was centrifuged at 3000rpm for 5 minutes to obtain serum. Heart and liver tissues were harvested, blotted, rinsed in $1.15 \% \mathrm{KCl}$ and homogenized in aqueous Tris- $\mathrm{HCl}$ buffer (50 mM, pH 7.4). Homogenates were centrifuged at 10,000 g for 20 $\min$ at $-4{ }^{\circ} \mathrm{C}$ to obtain the supernatant which were used for analyses. The supernatant and serum obtained were stored at $-20^{\circ} \mathrm{C}$ for various biochemical analyses.

\section{Biochemical assay}

Determination of total protein concentration: Serum $(0.1 \mathrm{ml})$ was dissolved in $3.9 \mathrm{ml}$ of $0.9 \%$ saline to give a 1 in 40 dilution. Exactly $3 \mathrm{ml}$ of Biuret reagent was added to $2 \mathrm{ml}$ of the diluted sample. The mixture was left at room temperature for 30 minutes after which the absorbance was read at $540 \mathrm{~nm}$ [20].

\section{Serum parameters}

The levels of uric acid, urea, aspartate transaminase and alanine transaminase were estimated in serum using assay kits according to the instructions of the manufacturer.

\section{Antioxidant assay}

Lipid peroxidation: Lipid peroxidation was determined by measuring the formation of thiobarbituric acid reactive substances (TBARS) according to the method of [21]. An aliquot of $0.4 \mathrm{ml}$ of the tissue was mixed with $1.6 \mathrm{ml}$ of Tris- $\mathrm{KCl}$ buffer to which $0.5 \mathrm{ml}$ of $30 \%$ TCA was added. Then $0.5 \mathrm{ml}$ of $0.75 \%$ TBA was added and placed in a water bath for 45 minutes at $80 \mathrm{oC}$. This was then cooled in ice and centrifuged at $3000 \mathrm{~g}$ The clear supernatant was collected and absorbance measured against a reference blank of distilled water at $532 \mathrm{~nm}$. Lipid peroxidation in units/mg protein or gram tissue was computed with a molar extinction coefficient of $1.56 \mathrm{x}$ $105 \mathrm{M}-1 \mathrm{Cm}-1$.

Estimation of reduced glutathione (GSH) level: The method of [22] was followed in estimating the level of reduced glutathione (GSH). $1 \mathrm{ml}$ of supernatant was precipitated with $5 \%$ sulphosalicylic acid $(1.5 \mathrm{ml})$ by gentle mixing and allowed to stand for $5 \mathrm{~min}$ before filtering. Thereafter, $0.5 \mathrm{ml}$ of filtrate was added to $2 \mathrm{ml}$ of $0.1 \mathrm{M}$ phosphate buffer ( $\mathrm{pH}$ 7.4) followed by Ellman's reagent 0.25 $\mathrm{ml}$ ). A blank was prepared with $2 \mathrm{ml}$ buffer, $0.5 \mathrm{ml}$ of diluted precipitating solution ( 3 parts to 2 parts of distilled water) and $0.25 \mathrm{ml}$ of Ellman's reagent. The optical density was measured at $412 \mathrm{~nm}$. GSH was proportional to the absorbance at that wavelength and the estimate was obtained from a GSH standard curve.

\section{Determination of Lee index}

Lee index was calculated according to [23] Bernardis (1970) using this formula.

$$
\text { Adiposity index }=\frac{\text { Cube root of body weight }(\mathrm{g})}{\text { Body length }(\mathrm{cm})}
$$

\section{Cardioprotective study}

The experimental animals were divided into nine groups of five animals each. The treatment was carried out as shown below. 
Group I: Fed with standard rodent chow only (negative control)

Group II: Fed with standard rodent chow $+15 \mathrm{mg} / \mathrm{kg}$ DOX (induced group)

Group III: Fed with 30\% germinated C. maxma seed flour +15 $\mathrm{mg} / \mathrm{kg}$ DOX

Group IV: Fed with $60 \%$ germinated C. maxma seed flour +15 $\mathrm{mg} / \mathrm{kg}$ DOX

Group V: Fed with 30\% fermented C. maxma seed flour + 15 $\mathrm{mg} / \mathrm{kg}$ DOX

Group VI: Fed with 60\% fermented C. maxma seed flour + 15 $\mathrm{mg} / \mathrm{kg}$ DOX

Group VII: Fed with 30\% roasted C. maxma seed flour + 15 $\mathrm{mg} / \mathrm{kg}$ DOX

Group VII: Fed with 60\% roasted C. maxma seed flour +15 $\mathrm{mg} / \mathrm{kg}$ DOX

Group IX: Fed with standard rodent chow $+10 \mathrm{mg} / \mathrm{kg}$ ramipril

All the groups were fed appropriately on daily basis and were later challenged with single intraperitoneal dose of doxorubicin (15 $\mathrm{mg} / \mathrm{kg}$ b.wt.) on the $13^{\text {th }}$ day except the negative control which was administered the vehicle (normal saline 0.9\%) intraperitoneally. Animals were sacrificed $24 \mathrm{~h}$ after doxorubicin/vehicle administration. The supernatant and serum used for various biochemical analyses were obtained as discussed in section 2.7.

\section{Serum parameters}

The activities of aspartate transaminase and alanine transaminase were analysed as reported in section 2.7.1.2. Lactate dehydrogenase and creatine kinase activities, potassium and sodium ions, albumin level were estimated in serum according to the instructions of the manufacturer using assay kits from Randox laboratories, UK.

\section{Lipid profile}

Total cholesterol, triglyceride and high density lipoprotein were determined according to the instructions of the manufacturer using assay kits from Randox laboratories, UK. Serum very low density lipoprotein and low density lipoprotein were calculated according to [24] and [25] formulas respectively.

$$
V L D L=\frac{T G}{5} \quad L D L=[T C-H D L-(T G / 5)]
$$

VLDL = very low density lipoprotein, $\mathrm{TG}=$ triglyceride, $\mathrm{LDL}=$ low density lipoprotein, $\mathrm{TC}=$ total cholesterol, $\mathrm{HDL}=$ high density lipoprotein

\section{Antioxidant assay}

Determination of superoxide dismutase (SOD) activity: The activity profile of SOD in the homogenates was determined by the method of [26] Briefly, an aliquot of the diluted sample was added to $2.5 \mathrm{ml}$ of $0.05 \mathrm{M}$ carbonate buffer ( $\mathrm{pH} 10.2$ ) to equilibrate in the spectrophotometer and the reaction started by the addition of 0.3 $\mathrm{ml}$ of freshly prepared $0.3 \mathrm{mM}$ adrenaline to the mixture which was quickly mixed by inversion. The reference cuvette contained $2.5 \mathrm{ml}$ buffer, $0.3 \mathrm{ml}$ of substrate (adrenaline) and $0.2 \mathrm{ml}$ of water. The increase in absorbance at $480 \mathrm{~nm}$ was monitored every 30 seconds for 150 seconds. 1 unit of SOD activity was given as the amount of SOD necessary to cause $50 \%$ inhibition of the oxidation of adrenaline to adrenochrome for 1 minute.

Determination of reduced glutathione concentration and extent of lipid peroxidation: Reduced glutathione and lipid peroxidation assays were carried out as reported in section 2.7.2.

\section{Determination of atherogenic index}

Atherogenic index was measured with formula according to [27].

$$
A I=\frac{T C-H D L}{H D L}
$$

Where $\mathrm{AI}=$ Atherogenic index, $\mathrm{TC}=$ Total cholesterol, $\mathrm{HDL}=$ High density lipoprotein

\section{Statistical analysis}

Results were analysed using appropriate analysis of variance (ANOVA) followed by Duncan multiple range tests. In all the tests, $p<0.05$ was taken as criterion for statistical significance. The statistical software used to analyze the data was GraphPad Prism 6.01 (GraphPad Software Inc., CA, USA).

\section{Result}

The antioxidant properties of pumpkin seed flour is presented in (Table 1). Cucurbita maxima seed flour exhibited a good antioxidant property with fermented sample having the highest in respect to DPPH (56.75\%), ABTS (22.57mmol/g), vitamin C $(11.60 \mathrm{mg}$ $\mathrm{AEE} / 100 \mathrm{~g}$ ) and total flavonoid (1.15 mg QE/g). (Table 2) shows the results of the acute toxicological effect of processed C. maxima seed flour on the serum biochemical parameters. There were increase in the activities/levels of alanine transaminase (8.98 U/L - 25.65 $\mathrm{U} / \mathrm{L}$ ), aspartate transaminase (5.38 U/L - $59.11 \mathrm{U} / \mathrm{L})$, total protein (33.44 mg/dl - $53.63 \mathrm{mg} / \mathrm{gl})$, uric acid $(7.02 \mathrm{mg} / \mathrm{dl}-35.16 \mathrm{mg} /$ $\mathrm{dl})$ and urea $(21.91 \mathrm{mg} / \mathrm{dl}-46.91 \mathrm{mg} / \mathrm{dl})$ and compared well with the control group with the exception of germinated sample. From (Table 3), concentrations of MDA, GSH in heart and liver was observed to also compare well with the control group. Data in (Figure 1) showed the Lee index (0.14 - 0.18) of the experimental rats with no significant difference. Processed C. maxima seed treated groups III - IX showed a significant $(\mathrm{p}<0.001)$ decrease in the level of serum marker enzymes and increase in the albumin level when compared with DOX-toxified rats (Table 4). Changes in lipid profile due to drug effect and its control by processed C. maxima seed is presented in (Table 5). Significant decrease in serum HDL and concomitant in- 
crease in serum TC, LDL, VLDL and TAG levels in doxorubicin intoxicated rats were observed. The results showed processed C. maxima seed flour compared well with the induced group in reversing the alterations caused by doxorubicin in serum lipid profile of Wistar rats. Doxorubicin administration produced significant elevation in MDA concentration and reduction in cardiac activities of GSH and SOD as compared with the pretreated groups. Doxorubicin toxicity in rats resulted in oxidative stress as evidenced by the reduction in myocardial antioxidant enzyme activities (Table 6). These anomalies were prevented upon pretreatment with processed C. maxima seed flour which restored the altered levels of antioxidant indices to normal control values. Rats that were administered with DOX alone showed a significant $(\mathrm{p}<0.001)$ decrease and increase in the potassium ion and sodium ion levels as compared to the normal control and pretreated rats (Table 7). Pretreatment with processed C. maxima seed flour samples were able to restore the altered levels of the electrolytes to normal control values. The effect of processed C. maxima seed flour on the biochemical and cardiac antioxidant parameters of doxorubicin-toxified rats (Tables 4-7) suggests a dose influence with the highest protective effect at $60 \%$ of fermented C. maxima seed flour. Processed C. maxima seed treated groups III IX revealed reduction in the level of atherogenic index when compared with DOX alone intoxicated rats (Figure 2).

Table 1: Antioxidant properties of processed Cucurbita maxima seed flour.

\begin{tabular}{|c|c|c|c|c|}
\hline Samples & Raw pumpkin seed flour & $\begin{array}{l}\text { Fermented pumpkin seed } \\
\text { flour }\end{array}$ & $\begin{array}{l}\text { Germinated pumpkin seed } \\
\text { flour }\end{array}$ & Roasted pumpkin seed flour \\
\hline Total phenol & \multirow{2}{*}{$0.97 \pm 0.00^{\mathrm{d}}$} & \multirow{2}{*}{$1.03 \pm 0.00^{c}$} & \multirow{2}{*}{$1.95 \pm 0.01^{\mathrm{a}}$} & \multirow{2}{*}{$1.08 \pm 0.00^{\mathrm{b}}$} \\
\hline (mg GAE/g) & & & & \\
\hline Total flavonoid & \multirow{2}{*}{$0.21 \pm 0.01^{\mathrm{b}}$} & \multirow{2}{*}{$1.15 \pm 0.01^{\mathrm{a}}$} & \multirow{2}{*}{$0.37 \pm 0.01^{\mathrm{b}}$} & \multirow{2}{*}{$0.17 \pm 0.00^{\mathrm{d}}$} \\
\hline (mg QE/g) & & & & \\
\hline Vitamin C & \multirow{2}{*}{$9.52 \pm 0.06^{b}$} & \multirow{2}{*}{$11.60 \pm 0.03^{\mathrm{a}}$} & \multirow{2}{*}{$11.56 \pm 0.01^{\mathrm{a}}$} & \multirow{2}{*}{$6.70 \pm 0.09^{c}$} \\
\hline (mg AEE/100g) & & & & \\
\hline FRAP (mg/g) & $42.85 \pm 0.18^{\mathrm{d}}$ & $50.59 \pm 0.04^{\mathrm{b}}$ & $59.03 \pm 0.18^{\mathrm{a}}$ & $48.80 \pm 0.34^{c}$ \\
\hline DPPH (\%) & $41.98 \pm 0.25^{c}$ & $56.75 \pm 1.04^{\mathrm{a}}$ & $6.48 \pm 0.25^{\mathrm{d}}$ & $49.79 \pm 0.45^{\mathrm{b}}$ \\
\hline ABTS (mmol/g) & $21.88 \pm 0.13^{b}$ & $22.57 \pm 0.23^{\mathrm{a}}$ & $16.01 \pm 0.20^{\mathrm{d}}$ & $21.64 \pm 0.13^{c}$ \\
\hline
\end{tabular}

Means of triplicate determinations \pm S.D. Means with different superscripts on the same row are significantly different at $p<0.05$

Table 2: Acute toxicological effect of processed pumpkin seed flour on the serum biochemical indices of Wistar rats.

\begin{tabular}{|c|c|c|c|c|c|}
\hline Groups & $\begin{array}{c}\text { Alanine } \\
\text { transaminase }(\mathrm{U} / \mathrm{L})\end{array}$ & $\begin{array}{c}\text { Aspartate } \\
\text { transaminase }(\mathrm{U} / \mathrm{L})\end{array}$ & $\begin{array}{l}\text { Total protein } \\
\text { (mg/gl) }\end{array}$ & $\begin{array}{l}\text { Uric acid } \\
\text { (mg/dl) }\end{array}$ & $\begin{array}{c}\text { Urea } \\
\text { (mg/dl) }\end{array}$ \\
\hline Control & $8.98 \pm 0.57$ & $5.38 \pm 2.38$ & $43.51 \pm 0.28$ & $7.02 \pm 0.64$ & $21.91 \pm 0.46$ \\
\hline Germinated & $25.65 \pm 1.55^{* * *}$ & $59.11 \pm 1.10^{* * *}$ & $33.44 \pm 0.12^{* * *}$ & $27.33 \pm 0.64^{* * *}$ & $46.91 \pm 0.19^{* * *}$ \\
\hline Fermented & $13.92 \pm 3.29 *$ & $19.86 \pm 2.88^{* * *}$ & $53.63 \pm 0.07^{* * *}$ & $19.57 \pm 0.64^{* * *}$ & $42.60 \pm 0.75^{* * *}$ \\
\hline Roasted & $10.27 \pm 0.98$ & $10.58 \pm 2.59$ & $50.87 \pm 0.30 * *$ & $35.16 \pm 0.64^{* * *}$ & $44.94 \pm 0.94^{* * *}$ \\
\hline
\end{tabular}

Results are expressed as Mean $\pm \mathrm{SD}(\mathrm{n}=5)$. \#\#\#p<0.001 vs control, ${ }^{*} \mathrm{p}<0.1,{ }^{* *} \mathrm{P}<0.01,{ }^{* * *} \mathrm{p}<0.001 \mathrm{vs} \mathrm{DOX}(15 \mathrm{mg} / \mathrm{kg})$

Table 3: Acute toxicological effect of processed pumpkin seed flour on some antioxidant parameters in Wistar rats.

\begin{tabular}{|c|c|c|c|c|}
\hline \multirow[b]{2}{*}{ Groups } & \multicolumn{2}{|c|}{ MDA Concentration ( $\mu \mathrm{M} / \mathrm{mg}$ protein) } & \multicolumn{2}{|c|}{ GSH (mMol.mg protein) } \\
\hline & Heart & Liver & Heart & Liver \\
\hline Control & $5.90 \pm 0.49$ & $5.06 \pm 0.08$ & $29.37 \pm 0.53$ & $22.94 \pm 0.64$ \\
\hline Germinated & $11.03 \pm 0.86^{* * *}$ & $7.24 \pm 0.30^{* * *}$ & $24.81 \pm 0.00^{* * *}$ & $16.57 \pm 0.31^{* * *}$ \\
\hline Fermented & $5.84 \pm 0.61$ & $4.88 \pm 0.16$ & $28.59 \pm 0.51$ & $21.46 \pm 0.27^{*}$ \\
\hline Roasted & $7.58 \pm 0.55^{*}$ & $5.52 \pm 0.15^{*}$ & $26.17 \pm 1.80^{* * *}$ & $20.60 \pm 0.91^{* * *}$ \\
\hline
\end{tabular}

Results are expressed as Mean $\pm S D(n=5)$. \#\#\#p<0.001 vs control, ${ }^{*} p<0.1,{ }^{* *} p<0.01,{ }^{* *} p<0.001 \mathrm{vs} \mathrm{DOX} \mathrm{(15} \mathrm{mg/kg)}$

Table 4: Effect of processed pumpkin seed flour on the serum biochemical indices of doxorubicin intoxicated Wistar rats

\begin{tabular}{|c|c|c|c|c|c|}
\hline Groups & $\begin{array}{c}\text { Aspartate transaminase } \\
\text { (U/L) }\end{array}$ & $\begin{array}{c}\text { Alanine transaminase } \\
\text { (U/L) }\end{array}$ & Albumin (g/l) & $\begin{array}{c}\text { Lactate dehydroge- } \\
\text { nase }(U / L)\end{array}$ & $\begin{array}{c}\text { Creatine kinase } \\
\text { (U/L) }\end{array}$ \\
\hline Control & $43.75 \pm 1.44$ & $35.07 \pm 0.02$ & $49.15 \pm 1.08$ & $1554.24 \pm 45.79$ & $565.30 \pm 9.54$ \\
\hline DOX (15mg/kg) & $70.26 \pm 5.77 \# \# \#$ & $44.12 \pm 0.04 \# \# \#$ & $37.64 \pm 1.62 \# \# \#$ & 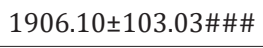 & $944.42 \pm 19.08 \# \# \#$ \\
\hline DOX + GPSF (30\%) & $68.05 \pm 0.36^{* * *}$ & $41.45 \pm 0.03^{* * *}$ & $40.34 \pm 4.08$ & $1689.16 \pm 11.45^{* *}$ & $859.42 \pm 40.07^{* * *}$ \\
\hline DOX + GPSF (60\%) & $62.45 \pm 2.88^{* * *}$ & $43.36 \pm 0.04^{* * *}$ & $42.29 \pm 1.13$ & $1594.18 \pm 50.37^{* * *}$ & $752.84 \pm 11.45^{* * *}$ \\
\hline DOX + FPSF (30\%) & $51.40 \pm 1.80^{* * *}$ & $37.68 \pm 0.01^{* * *}$ & $42.72 \pm 2.17$ & $1493.80 \pm 132.80^{* * *}$ & $751.49 \pm 36.25^{* * *}$ \\
\hline
\end{tabular}




\begin{tabular}{|c|c|c|c|c|c|}
\hline DOX + FPSF (60\%) & $42.90 \pm 0.72^{* * *}$ & $34.78 \pm 0.01^{* * *}$ & $51.16 \pm 3.76^{* * *}$ & $1315.71 \pm 82.42^{* * *}$ & $568.00 \pm 24.80^{* * *}$ \\
\hline DOX + RPSF (30\%) & $55.48 \pm 0.36^{* * *}$ & $39.07 \pm 0.01^{* * *}$ & $42.21 \pm 4.12$ & $1713.98 \pm 9.16^{* *}$ & $812.20 \pm 11.45^{* * *}$ \\
\hline DOX + RPSF (60\%) & $49.87 \pm 0.72^{* * *}$ & $37.15 \pm 0.04^{* * *}$ & $47.76 \pm 1.34^{* * *}$ & $1495.96 \pm 16.03^{* * *}$ & $605.78 \pm 28.62^{* * *}$ \\
\hline $\begin{array}{c}\text { DOX + RAM } \\
\mathbf{( 1 0 m g / k g ) ~}\end{array}$ & $42.73 \pm 0.72^{* * *}$ & $34.83 \pm 0.02^{* * *}$ & $49.44 \pm 1.08^{* * *}$ & $1508.91 \pm 22.90^{* * *}$ & $547.76 \pm 3.82^{* * *}$ \\
\hline
\end{tabular}

Results are expressed as Mean $\pm S D(n=5)$. \#\#\#p<0.001 vs control, ${ }^{*} p<0.1,{ }^{* *} p<0.01,{ }^{* * *} p<0.001$ vs DOX (15 mg/kg)

RPSF: raw pumpkin seed flour, FPSF: fermented pumpkin seed flour; GPSF: germinated pumpkin seed flour; ROPSF: roasted pumpkin seed flour, DOX: doxorubincin, RAM: ramipril

Table 5: Effect of processed pumpkin seed flour on the serum lipid profile of doxorubicin intoxicated Wistar rats.

\begin{tabular}{|c|c|c|c|c|c|}
\hline Groups & $\begin{array}{c}\text { Total cholester- } \\
\text { ol (mg/dl) }\end{array}$ & $\begin{array}{c}\text { Triglyceride } \\
\text { (mg/dl) }\end{array}$ & $\begin{array}{c}\text { High density lipoprotein } \\
\text { (mg/dl) }\end{array}$ & $\begin{array}{c}\text { Low density lipopro- } \\
\text { tein (mg/dl) }\end{array}$ & $\begin{array}{c}\text { Very low density lipoprotein } \\
\text { (mg/dl) }\end{array}$ \\
\hline Control & $100.83 \pm 5.83$ & $76.25 \pm 5.26$ & $57.29 \pm 4.86$ & $28.29 \pm 16.33$ & $15.25 \pm 0.26$ \\
\hline $\begin{array}{c}\text { DOX (15 mg/ } \\
\text { kg) }\end{array}$ & $149.88 \pm 4.96 \# \# \#$ & $158.71 \pm 3.95 \# \# \#$ & $29.79 \pm 3.97 \# \# \#$ & $88.34 \pm 11.58 \# \# \#$ & $31.74 \pm 0.79 \# \# \#$ \\
\hline $\begin{array}{c}\text { DOX + GPSF } \\
\mathbf{( 3 0 \% )}\end{array}$ & $126.96 \pm 17.50^{*}$ & $156.22 \pm 6.58^{* * *}$ & $37.58 \pm 2.26^{* *}$ & $58.13 \pm 19.19^{*}$ & $31.25 \pm 0.00$ \\
\hline $\begin{array}{c}\text { DOX + GPSF } \\
\mathbf{( 6 0 \% )}\end{array}$ & $117.33 \pm 5.83^{* * *}$ & $120.27 \pm 7.89^{* * *}$ & $46.75 \pm 0.79^{* * *}$ & $46.53 \pm 21.12^{* * *}$ & $24.05 \pm 0.47^{* * *}$ \\
\hline $\begin{array}{c}\text { DOX + FPSF } \\
\mathbf{( 3 0 \% )}\end{array}$ & $116.42 \pm 9.16^{* * *}$ & $86.79 \pm 8.97^{* * *}$ & $40.56 \pm 1.46^{* * *}$ & $58.50 \pm 11.67^{*}$ & $17.36 \pm 0.18^{* * *}$ \\
\hline $\begin{array}{c}\text { DOX + FPSF } \\
\mathbf{6 0 \% )}\end{array}$ & $107.71 \pm 3.24^{* * *}$ & $73.77 \pm 5.37^{* * *}$ & $55.00 \pm 1.95$ & $37.96 \pm 10.46^{* * *}$ & $14.76 \pm 0.36^{* * *}$ \\
\hline $\begin{array}{c}\text { DOX + RPSF } \\
\mathbf{( 3 0 \% )}\end{array}$ & $120.08 \pm 4.86^{* * *}$ & $102.91 \pm 3.95^{* * *}$ & $40.79 \pm 1.95^{* * *}$ & $58.71 \pm 8.99^{*}$ & $20.58 \pm 0.79^{* * *}$ \\
\hline $\begin{array}{c}\text { DOX + RPSF } \\
\mathbf{( 6 0 \% )}\end{array}$ & $113.21 \pm 8.29^{* * *}$ & $81.21 \pm 5.70^{* * *}$ & $54.54 \pm 0.97$ & $42.43 \pm 10.58^{* * *}$ & $16.24 \pm 0.68^{* * *}$ \\
\hline $\begin{array}{c}\text { DOX + RAM (10 } \\
\mathbf{m g} / \mathbf{~ k g )}\end{array}$ & $96.25 \pm 5.83^{* * *}$ & $75.01 \pm 6.14^{* * *}$ & $59.13 \pm 0.97$ & $15.00 \pm 0.61^{* * *}$ & $15.00 \pm 0.61^{* * *}$ \\
\hline
\end{tabular}

Results are expressed as Mean $\pm \mathrm{SD}(\mathrm{n}=5)$. \#\#\# $<0.001$ vs control, ${ }^{*} \mathrm{p}<0.1,{ }^{* *} \mathrm{p}<0.01,{ }^{* * *} p<0.001 \mathrm{vs} \mathrm{DOX}(15 \mathrm{mg} / \mathrm{kg})$

RPSF: raw pumpkin seed flour, FPSF: fermented pumpkin seed flour; GPSF: germinated pumpkin seed flour; ROPSF: roasted pumpkin seed flour, DOX: doxorubicin, RAM: ramipril.

Table 6: Effect of processed pumpkin seed flour on the cardiac antioxidant parameters of doxorubicin intoxicated rats.

\begin{tabular}{|c|c|c|c|}
\hline Groups & MDA concentration ( $\mu$ M/ mg protein) & GSH (mMol.mg protein) & SOD (U/mg protein) \\
\hline Control & $8.45 \pm 0.05$ & $19.93 \pm 0.46$ & $2.12 \pm 0.00$ \\
\hline DOX (15 $\mathbf{~ m / k g ) ~}$ & $13.06 \pm 0.10 \# \# \#$ & $9.30 \pm 0.63 \# \# \#$ & $1.36 \pm 0.17 \# \# \#$ \\
\hline DOX + GPSF (30\%) & $10.00 \pm 0.05^{* * *}$ & $10.55 \pm 0.51$ & $1.75 \pm 0.00^{* * *}$ \\
\hline DOX + GPSF (60\%) & $8.62 \pm 0.16^{* * *}$ & $17.83 \pm 0.39^{* * *}$ & $1.87 \pm 0.00^{* * *}$ \\
\hline DOX + FPSF (30\%) & $9.28 \pm 0.10^{* * *}$ & $13.02 \pm 0.88^{* * *}$ & $1.74 \pm 0.00^{* * *}$ \\
\hline DOX + FPSF (60\%) & $8.35 \pm 0.16^{* * *}$ & $21.05 \pm 0.64^{* * *}$ & $2.65 \pm 0.00^{* * *}$ \\
\hline DOX + RPSF (30\%) & $9.62 \pm 0.10^{* * *}$ & $11.25 \pm 0.97^{*}$ & $2.30 \pm 0.00^{* * *}$ \\
\hline DOX + RPSF (60\%) & $8.75 \pm 0.10^{* * *}$ & $19.16 \pm 1.31^{* * *}$ & $2.44 \pm 0.00^{* * *}$ \\
\hline DOX + RAM (10 $\mathbf{~ m g / ~ k g ) ~}$ & $8.22 \pm 0.17^{* * *}$ & $22.86 \pm 0.46^{* * *}$ & $2.97 \pm 0.17^{* * *}$ \\
\hline
\end{tabular}

Results are expressed as Mean $\pm \mathrm{SD}(\mathrm{n}=5)$. \#\#\#<0.001 vs control, ${ }^{*} \mathrm{p}<0.1,{ }^{* *} \mathrm{p}<0.01,{ }^{* * *} \mathrm{p}<0.001 \mathrm{vs} \mathrm{DOX}(15 \mathrm{mg} / \mathrm{kg})$

RPSF: raw pumpkin seed flour, FPSF: fermented pumpkin seed flour; GPSF: germinated pumpkin seed flour; ROPSF: roasted pumpkin seed flour, DOX: doxorubincin, RAM: ramipril

Table 7: Effect of processed pumpkin seed flour on the cardiac serum electrolytes of doxorubicin intoxicated Wistar rats.

\begin{tabular}{|c|c|c|}
\hline Groups & Potassium (mEq/l) & Sodium (mEq/l) \\
\hline Control & $4.55 \pm 0.22$ & $37.43 \pm 0.57$ \\
\hline DOX (15 $\mathbf{~ m g / k g ) ~}$ & $3.04 \pm 0.28 \# \# \#$ & $79.31 \pm 3.46 \# \# \#$ \\
\hline DOX + GPSF (30\%) & $3.10 \pm 0.24$ & $70.70 \pm 0.72^{* * *}$ \\
\hline DOX + GPSF (60\%) & $3.88 \pm 0.20^{*}$ & $66.34 \pm 0.98^{* * *}$ \\
\hline
\end{tabular}




\begin{tabular}{|c|c|c|}
\hline DOX + FPSF (30\%) & $3.84 \pm 0.19^{*}$ & $64.89 \pm 2.04^{* * *}$ \\
\hline DOX + FPSF (60\%) & $4.56 \pm 0.10^{* * *}$ & $42.33 \pm 0.83^{* * *}$ \\
\hline DOX + RPSF (30\%) & $3.61 \pm 0.37$ & $67.52 \pm 0.39^{* * *}$ \\
\hline DOX + RPSF (60\%) & $4.31 \pm 0.64^{* *}$ & $50.03 \pm 0.72^{* * *}$ \\
\hline DOX + RAM (10 $\mathbf{~ m g / ~ k g ) ~}$ & $4.51 \pm 0.61^{* * *}$ & $39.97 \pm 2.59^{* * *}$ \\
\hline
\end{tabular}

Results are expressed as Mean $\pm S D(n=5)$. \#\#\#p<0.001 vs control, ${ }^{*} p<0.1,{ }^{* *} p<0.01,{ }^{* * *} p<0.001$ vs DOX (15 mg/kg)

RPSF: raw pumpkin seed flour, FPSF: fermented pumpkin seed flour; GPSF: germinated pumpkin seed flour; ROPSF: roasted pumpkin seed flour,

DOX: doxorubincin, RAM: ramipril

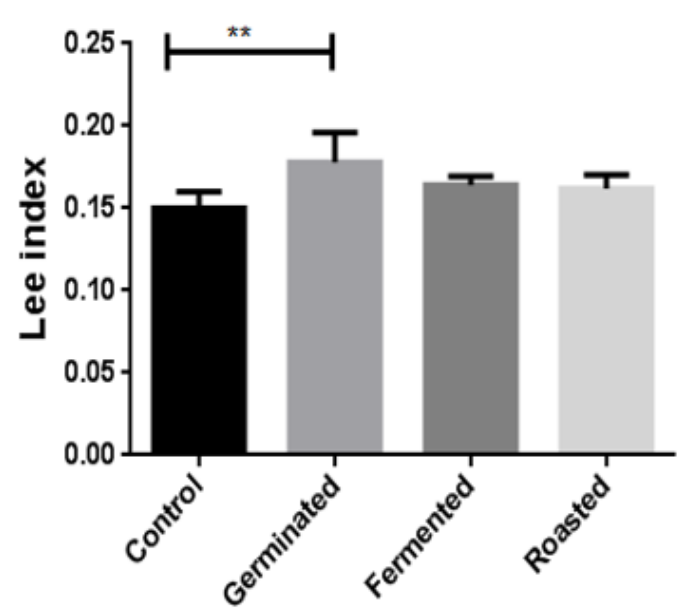

Figure 1: Lee index of Wistar rats on acute toxicology of processed pumpkin seed flour.

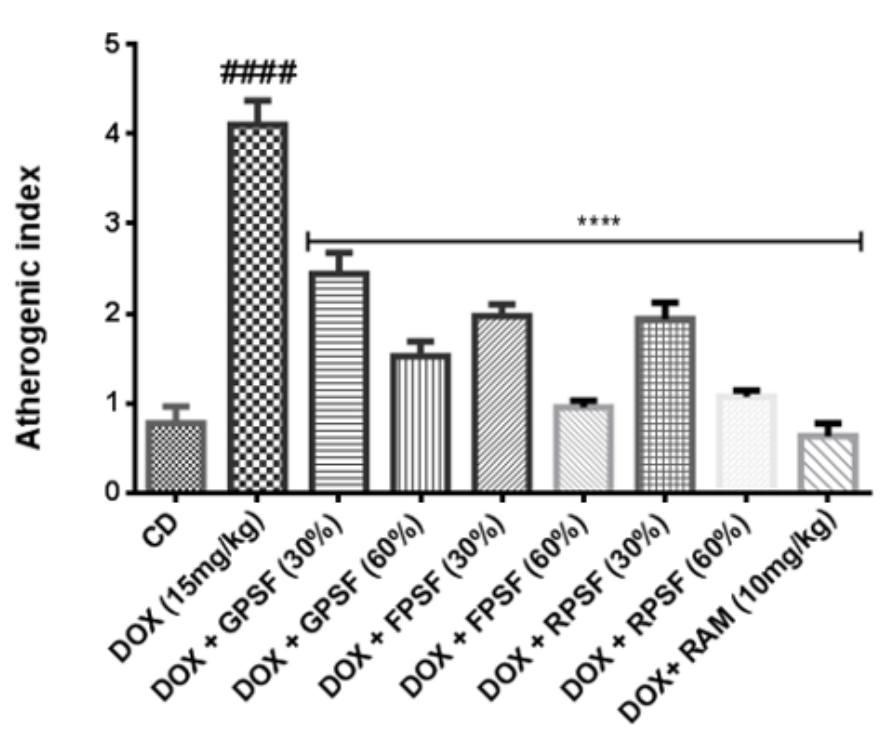

Figure 2: Atherogenic index on doxorubicin intoxicated Wistar rats fed with processed pumpkin seed flour.

\section{Discussion}

Plants have been pertinent to humans as medicinal sources and many modern drugs have been derived from secondary plant metabolites. Since time immemorial, mankind has been dependent on plants for their curative properties [28]. This property was attributed to the presence of phytochemicals, which has also formed as the basis for drug development [29]. Some of these phytochemicals has been reported to be a good source of antioxidant and this attribute made them useful in the management of diseases. Fruits and vege- tables are good sources of antioxidant like pumpkin seed which can mitigate oxidative stress induced tissue injury [30,31]. The result of antioxidant properties of processed Cucurbita maxima seed flour gives an insight into the therapeutic potentials of plant. This probably explains the earlier reported medicinal uses of C. maxima seed [32-34]. Acute toxicological assessment is often employed as a pilot test when investigating the toxicity of substances and aims at deciphering the threshold of tolerance in an animal model [35]. Liver is the major organ responsible for metabolism and system detoxifica- 
tion [36]. The liver function tests revealed a toxin-triggered siege on the liver's integrity, albeit normal functioning of the liver. Alterations in alanine transaminase (ALT) and aspartate transaminase AST) activities indicate damage to liver. Feeding of the animals on $100 \%$ germinated pumpkin seed resulted in significant alteration of ALT and AST. This contradicts report of [37] who worked cholesterol-lowering and liver-protective effects of cooked and germinated mung beans (Vigna radiata L.). The contradiction is based on the fact that [37] used diet inclusion while this research was based on $100 \%$ diet. Fermented and roasted samples compared well with control sample on AST and ALT levels. The result from this study supports earlier report of [38] who observed acute toxicity and vascular properties of roasted and fermented Parkia biglobosa on rat's aorta. However, uric acid and urea levels presented abnormal alterations when compared with the control group, which can be related to the protection of the catabolism or high protein diet, therefore the urinary flow of the rats was considered normal [39]. The study revealed that processed C. maxima increased the level of total protein, and this can be justified by the chemical composition and favorable nutritional value of the pumpkin seed [39].

The low level of MDA production and high concentration of reduced glutathione depicts high degree of the antioxidant capacity of an organ. Reduced glutathione is the body's key antioxidant and protective agent [40]. It's involved in detoxification of xenobiotics that cause toxicity and has a variety of functions in the prevention of diseases and in the detoxification of chemicals and drugs while its depletion is associated with increased risk of toxicity and diseases [40]. The significant increase in the extent of LPO accompanied by a significant decrease in GSH in the group fed with germinated C. maxima seed flour caused alteration in these parameters in the heart and liver of the experimental rats. The antioxidant capacity of the organ was compromised which could also account for the leakage of the liver enzymes. Lee index can be used as a fast and accurate way to determine obesity in rats [41]. The result sets the nutritional content as a measure of obesity. The results below 0.300 are considered normal which is supported by this finding [41]. Processed C. maxima seed flour ameliorate the weight of the animals and likewise did not lead to obesity. Eating behaviour is an integral part of nutritional research [42].

In another study, the effect of the processed pumpkin seed on doxorubicin intoxication was investigated. The cardiac enzymes, ALT, AST CK and LDH are abundant in cardiac muscle, particularly CK and LDH. In clinical settings, an elevation of cardiac enzymes in serum is considered a vital biomarker of myocardial damage, indicating a number of cardiac diseases, such as myocarditis and myocardial infarction and detecting the activities of these enzymes in serum is essential for assessing myocardial damage [43] The increase in serum cardiac enzymes following DOX administration in rats has been reported previously $[43,44]$. Serum CK activity is a more sensitive indicator of early stage of myocardial ischemia whereas LDH activity give a rough estimate of the extent of injury to myocardial tissues $[44,45]$. Administration of processed C. maxima seed flour especially fermented sample at $60 \%$ dose caused a decrease in the activities of cardiac enzymes (ALT, AST, LDH and CK) markers and increase albumin level in a dose dependent manner. The result is in agreement with previous works done on fermented food products where the induced serum markers were significantly restored back to normal through in vivo and in vitro studies $[46,47]$. Since the levels of these cellular enzymes present in the blood are directly related to the intactness of the plasma membrane of the cardiac cells, then the mitigation of DOX-induced injury and dose-dependent reduction in serum levels of these marker enzymes and elevation in albumin level by processed C. maxima seed flour could be due to its action on maintaining cardiac membrane integrity and restricting the leakage of these enzymes [48].

Elevated total cholesterol, triglycerides, LDL, VLDL and lower concentration of functional HDL which promotes atherosclerotic progression are associated with cardiovascular diseases [44,49]. As revealed in the present study, the ability of processed C. maxima seed flour to adapt the lipid profile of rats administered doxorubicin portends good signal for cardio protection, taken into consideration the role dyslipidemia plays in the etiology and progression of many cardiovascular diseases [50] reported that germinated and fermented mung bean lowered the cholesterol and triglyceride levels in Wistar rats. Also, the same observation was documented by [37] on the cholesterol-lowering and liver-protective effects of cooked and germinated mung beans (Vigna radiata L.). The result of roasted sample on serum lipid profile corroborates with what was reported by [51]. The reduction in the total cholesterol, triglycerides, low density lipoprotein, very low density lipoprotein and significant rise in high density lipoprotein in test animals is an indication that the seed flour of C. Maxima has some hypolipidemic properties and are of great significance in cardiovascular diseases management [52] reported that this could probably be due to the presence of flavanoids, phenols, etc in Cucurbita maxima seed. Elevation was observed in MDA concentration as well as reduction in GSH and SOD level/activity of cardiac antioxidants in DOX-toxicified groups. Treatment with processed C. maxima seed flour significantly reversed the changes made on levels of antioxidant parameters. Cardiotonic activity of Cucurbita maxima seed has been reported by [53] which is supported by this study. Reduced level of GSH and SOD activity may promote oxidative stress and membrane lipid peroxidation [54]. The observed decrease in SOD activity and concentration of GSH in the hearts of DOX-intoxicated rats strongly support the hypotheses that increased oxidative stress associated with an impaired antioxidant defense status is one mechanisms of doxorubicin toxicity [45]. In this study, pretreatment with processed C. maxima seed flour protected the heart from DOX-induced injury. The overall protective effect of processed Cucurbita maxima seed flour is probably due to counter action of free radicals by its antioxidant nature hence its ability to restore normalcy in tissue under oxidative stress [55].

Electrolytes are minerals in the body, they are acid, base or salts that regulate the body and fluid balance. There was a decrease in 
plasma potassium ion in the group administered with DOX as compared with the normal control group as cardiomyopathy caused hypokalemia and it was reversed when the intoxicated groups were treated with processed Cucurbita maxima seed flour. Potassium is critical to the maintenance of cardiovascular health especially in the at-risk cardiovascular patient. However, it has been reported that high intake should be encouraged [56]. High intakes of sodium have been reported to be associated with an increased risk of cardiovascular disease especially heart disease [57]. Plasma sodium ion was elevated in rats intoxicated with DOX compared with the normal control, and there was observed a decrease in elevated ion to normal values in groups who received processed Cucurbita maxima seed flour as it was also reported previously that elevated sodium ion was seen in rats having cardiac damage [58] Atherogenic index denotes the magnitude of the potential occurrence of atherosclerosis [59]. The higher of atherogenic index, the potential occurrence of atherosclerosis. Rats treated with processed $\mathrm{C}$. maxima seed flour lowered the atherogenic level as compared to DOX-toxified group which implies that the atherogenic index was affected by the content of HDL. The total cholesterol and HDL-C levels affect atherogenic index value. Reducing total cholesterol and increasing HDL-C levels reduce the atherogenic index value, so the risk of atherosclerosis will be smaller [60]. Overall, fermented Cucurbita maxima seed flour especially at $60 \%$ dose possessed the best antioxidant and cardioprotective effect. This result gives us an idea that fermentation played a more important role since we have observed better improvement of antioxidant activity in fermented than roasted and germinated Cucurbita maxima seed flour.

\section{Conclusion}

The present study demonstrates the protective effect of processed Cucurbita maxima seed flour against doxorubicin-induced cardiotoxicity and lends claim to the ethnopharmacological use of plant in the treatment of cardiovascular-related disorders. Also, fermented Cucurbita maxima seed at $60 \%$ is the most well tolerated due to low toxicity effect. The observed cardioprotective potential in Cucurbita maxima seed flour might be due to its antioxidant and antihyperlipidemic activities which denotes that processed Cucurbita maxima seed can be used as supplements. However, further studies are warranted to characterize the active phytoconstituents involved in the cardio protection.

\section{Acknowledgment}

This research was supported by year 2016/2017 merged TETFUND research projects intervention.

\section{Conflict of Interest}

No conflicts of interest.

\section{References}

1. World Health Organization (2017) World Health Organization report 2017: Cardiovascular diseases (CVDs). Geneva, Switzerland: World Health Organization.

2. Seifried HE, Anderson DE, Fisher EI, Milner JA (2007) A review of the interaction among dietary antioxidants and reactive oxygen species. J Nutr Biochem 18: 567-579.
3. Adegoke 0, Awolola NA, Ajuluchukwu JN (2018) Prevalence and pattern of cardiovascular-related causes of out-of- hospital deaths in Lagos, $\mathrm{Ni}$ geria. Afr Health Sci 18: 942-949.

4. Simko F, Adamcova M (2018) What prevents cardioprotective drugs from reaching the market? Expert Rev Clin Pharmacol 11: 463-465.

5. Salouege I, Ali BR, Saïd BD, Elkadri N, Kourda N, et al. (2014) Evaluation and protection of doxorubicin toxicity in rats. J Cancer Res Ther 10: 274278.

6. Chatterjee K, Zhang J, Honbo N, Karliner JS (2010) Doxorubincin cardiomyopathy. Cardiology 115: 155-162.

7. Salouege I, Ali BR, Saïd BD, Elkadri N, Kourda N, et al. (2014) Evaluation and protection of doxorubicin toxicity in rats. J Cancer Res Ther 10: 274278.

8. Thippeswamy BS, Thakker SP, Tubachi S, Kalyani, GA, Netra MK, et al. (2009) Cardioprotection effect of Cucumis trigonus roxb on isoproterenol-induced myocardial infraction in rat. Am J Pharmacol Toxicol 4: 2937.

9. Kim MY, Kim EJ, Kim YN, Choi C, Lee, BH (2012) Comparison of the chemical compositions and nutritive values of various pumpkin (Cucurbitaceae) species and parts. Nutr Res Pract 6: 21-24.

10. Ahmed S, Ravi PS (2017) Pumpkin seed oil: An alternative medicine. Int Pharmacogn Phytochem Res 9: 223-227.

11. Ifesan BOT, Akintade AO, Gabriel Ajobiewe RAO (2017) Physicohemical and nutritional properties of Mucuna pruriens and Parkia biglobosa subjected to controlled fermentation. Int Food Res J 24: 2177-2184.

12. Badau MH, Nkama I, Jideani IA (2005) Phytic acid content and hydrochloric acid extractability of minerals in pearl millet as affected by germination time and cultivar. Food Chem 92: 425-435.

13. Abdulrahaman AA, Olayinka BU, Andrauwus ZD, Aluko TA, Adebola MO, et al. (2014) Traditional preparations and uses of groundnut in Nigeria.

14. Singleton VL, Orthofer R, Lamuela-Raventos RM (1999) Analysis of total phenols and other oxidation substrates and antioxidants by means of Folin Ciocalteu reagent. Methods Enzymology 299: 152-177.

15. Bushra S, Farooq A, Muhammad A (2009) Effect of extraction solvent/ technique on the antioxidant activity of selected medicinal plant extracts. Molecules 14: 2167-2180.

16. Güçlü K, Sözgen K, Tütem E, Özyürek M, Apak R (2005) Spectrophotometric determination of ascorbic acid using copper (II)-neocuproine reagent in beverages and pharmaceuticals. Talanta 65: 1226-1232.

17. Pulido R, Bravo L, Saura-Calixto F (2000) Antioxidant activities of dietary polyphenols as determined by modified ferric reducing/antioxidant power assay. J Agric Food Chem 48: 3396-3402.

18. Butrits M, Bucar F (2000) Antioxidant activity of Nigeria sativa essential oil. Phytother Res 14: 323-328.

19. Re R, Pellegrini N, Proteggente A, Pannala A, Yang M, et al. (1999) Activityapplying an improved ABTS radical cation decolorization assay. Free Radic Biol Med 6: 1231-1223.

20. Tietz NW (1995) Clinical guide to laboratory test, $3^{\text {rd }}$ edition. WB Saunders Company, Philadelphia.

21. Ohkawa H, Ohishi N, Yagi K (1979) Assay for lipid peroxides in animal tissues by thiobarbituric acid reaction. Anal Biochem 95: 351-358.

22. Beutler E, Duron O, Kelly BM (1963) Improved method for the determination of blood glutathione. J lab and Clin Med 61: 882-888.

23. Bernardis LL (1970) Predicition of carcass fat, water and lean body mass from Lee's "nutritive ratio" in rats with hypothalamic obesity. Experientia 26: 789-790

24. Norbert WT (1995) Clinical Guide to Laboratory Tests, $3^{\text {rd }}$ edition. WB Saunders Company: Philadelphia.

25. Friedewald WT, Levy RI, Fredrickson DS (1972) Estimation of theconcentration of low density lipoprotein cholesterol in plasma without use of the preparative ultracentrifuge. Clin Chem 18: 499-502. 
26. Misra HP, Fridovich I (1972) The univalent reduction of oxygen by reduced flavins and quinines. J Biol Chem 247: 188-192.

27. Yokozawa T, Cho EJ, Sasaki S, Satoh A, Okamoto T, et al. (2006). The protective Chinese prescription kangen-karyu extract on diet induced hypercholesterolemia in rats. Biol Pharm Bull 29(4): 760-765.

28. Chari YK, Polu RP, Shenoy RR (2018) An appraisal of pumpkin seed extract in 1,2-dimethylhydrazine induced colon cancer in Wistar rats. J Toxicol 1: 1-12.

29. Muchirah PN, Waihenya R, Muya S, Abubakar L, Ozwara H, et al. (2018) Characterization and antioxidant activity of Cucurbita maxima Duchesne pulp and seed extracts. J Phytopharmacol 7: 134-140.

30. Parry J, Hao Z, Luther M, Su L, Zhou K, et al. (2006) Characterization of cold-pressed onion, parsley, cardamom, mullein, roasted pumpkin, and milk thistle seed oils. J Am Oil Chem Soc 83: 847-854.

31. Attarde DL, Kadu SS, Chaudhari, BJ, Bhamber RS (2010) In vitro antioxidant activity of pericarp of Cucurbita maxima Duch. Ex Lam. Int J Pharma Technol Res 2: 1533-1538.

32. Das R, Sahu J, Gupta RN (2010) Potentiative activity Of Cucurbita maxi$m a$ seed extract with Beta vulgaris and Smilax regelii root extract to reduce extra fats from the body. Int J Pharma Sci Res 1: 57-62.

33. Abd EI-Aziz AB, Abd EI-kalek HH (2011) Antimicrobial protein and oil seed from pumpkin. Nature and Science 9: 105-119.

34. Saha P, Bala A, Naskar S (2011) Antidiabetic activity of Cucurbita maxima aerial parts. Res J Med Plant 5: 577-586.

35. Ashafa AOT, Orekoya LO, Yakubu MT (2012) Toxicity profile of ethanolic extract of Azadirachta indica stem bark in male Wistar rats. Asian Pac J Trop Biomed 2: 811-817.

36. Ugbogu EA, Nwoku CD, Ude VC, Emmanuel O (2020) Evaluating bioactive constituents and toxicological effect of aqueous extract of fermented Pentaclethra macrophylla seeds in rats. Avicenna J Phytomed 10: 101113.

37. Lopes LAR, Martins MDCC, Farias LM, Brito AKS, Lima GDM, et al. (2018) Cholesterol-lowering and liver-protective effects of cooked and germinated mung beans (Vigna radiata L). Nutrients 10: 821-834.

38. Ouédraogo S, Somé N, Ouattara S, Kini FB, Traore A, et al. (2012) Acute toxicity and vascular properties of seed of Parkia biglobosa (jacq) r. br gift (mimosaceae) on rat aorta. Afr J Trad Complementary Altern Med 9: 260-265.

39. Cruz RCB, Meurer CD, Silva EJ, Schaefer C, Santos, ARS, et al. (2006) Toxicity evaluation of Cucurbita maxima seed extract in mice. Pharm Biol 44: 301-303.

40. Adepoju GKA, Adebanjo AA (1996) Effect of consumption on Cucurbita pepo seeds on haematological and biochemical parameters. African J Pharm Pharmacol 5: 18-22.

41. Malafia AB, Nassif PAN, Ribas CAMP, Ariede BL, Sue KL, et al. (2013) Obesity inductions with high fat sucrose in rats. Arquivos Brasileiros De Cirurgia Digestiva 26: 17-21.

42. Diniz YS, Cicogna A, Padovani C, Santana L, Faine L, et al. (2004) Diets rich in saturated and polyunsaturated fatty acids: metabolic shifting and cardiac health. Nutrition 20: 230-234.

43. Wu R, Yao P, Wang H, Gao Y, Yu H, et al. (2018) Effect of fermented Cordyceps sinensison Doxorubicin-induced cardiotoxicity in rats. Mol Med Rep 18: 3229-3241.

44. Crown 00, Olaleye MT, Akinmoladun, AC, Akindahunsi AA (2016) Salubrious effect of Parinari curatellifolla seed extract in doxorubicin intoxicated rats. Niger J Nat Prod Med 20: 73-80.
45. Komolafe K, Akinmoladun AC Olaleye MT (2013) Methanolic leaf extract of Parkia biglobosa protects against doxorubicin-induced cardiotoxicity in rats. Int J Appl Res Nat Prod 6: 39-47.

46. Kang YM, Qian ZJ, Lee BJ, Kim YM (2011) Protective effect of GABA enriched fermented sea tangle against ethanol induced cytotoxicity in HepG2 cells. Biotechnol Bioproc E 16: 966-970.

47. Zakaria ZA, Rofiee MS, Somchit MN, Zuraini A, Sulaiman MR, et al. (2011) Hepatoprotective activity of dried and fermented processed virgin coconut oil. Evid based Complementary Altern Med 2011: 142739.

48. Chen YF, Kobayashi S, Chen J (2008) Short term triodo-1-thyronine treatment inhibits cardiac myocyte apoptosis in border area after myocardial infarction in rats. J Mol Cell Cardiol 44: 180-187.

49. Crowwell WL, Otvos LD (2004) Low density lipoprotein particles number and risk for cardiovascular disease. Curr Artheroscler Rep 6: 381387.

50. Ali NM, Yusof HM, Long K, Yeap SK, Ho WY, et al. (2013) Antioxidant and hepatoprotective effect of aqueous extract of germinated and fermented mung bean on ethanol-mediated liver damage. BioMed Res Int 2013: 693613.

51. Woumbo CY, Kuate D, Womeni HM (2017) Cooking methods affect phytochemical composition and anti-obesity potential of soybean (Glycine max) seeds in Wistar rats.

52. Sharma A, Sharma AK, Chand T, Khardiya M, Yadav KC (2013) Antidiabetic and antihyperlipidemic activity of Cucurbita maxima Duchense (pumpkin) seeds on streptozotocin induced diabetic rats. J Pharmacogn Phytochem 1: 108-116.

53. Ranganathan V, Selvasubramanian S, Vasantha S (2013) Estimation in humoral response in rabbits fed with Cucrbita maxima seeds 6: 396-399.

54. Injac R, Radic H, Govedarica B (2009) Acute doxorubicin pulmotoxicity in rats with malignant neoplasm is effectively treated with fullerenol C60 $(\mathrm{OH}) 24$ through inhibition of oxidative stress. Pharmacol Rep 61(2): 335-342.

55. Xanthopoulou MN, Nomikos T, Fragopoulou E, Antonopoulou S (2009) Antioxidant and lipoxygenase inhibitory activities of pumpkin seed extracts. Food Res Int 42: 641-646.

56. Domenic SA, Allan SD, William CC, Mark W, John S, et al. (2002) Importance of potassium in cardiovascular disease. J Clin Hypertens 4: 198-206.

57. Graudal N, Jürgens G, Baslund B, Alderman MH (2014) Compared with usual sodium intake,low and excessive-sodium diets are associated with increased mortality: a meta-analysis. Am J Hypertens 27: 1129-1137.

58. Wang Y, Chao X, Ahmad F, Shi H, Mehboob H, et al. (2019) Phoenix dactylifera protects against doxorubicin-induced cardiotoxicity and nephrotoxicity. J Cardiol Res Pract 1: 1-8.

59. Prangdimurti E, Palupi dan NS, Zakaria FR (2007) Metode Evaluasi Nilai Biologis Karbohidrat dan Lemak. Modul e-Learning ENBP, Departemen Ilmu and Teknologi Pangan-Fateta-IPB.

60. Sa'adah NN, Purwani KI, Nurhayati ADP, Ashuri NM (2016) Analysis of lipid profile and atherogenic index in hyperlipidemic rat (Rattus norvegicus Berkenhout, 1769) that given the methanolic extract of parijoto (Medinilla speciosa). Proceeding of International Biology Conference. AIP Conference Proceeding 1854. 